\title{
PROTECTION AGAINST DETRIMENTAL EFFECTS FROM WATERS IN THE REPUBLIC OF SERBIA ${ }^{1}$
}

\author{
Nataša Kljajič, Vesna Popovic ${ }^{3}$, Biljana Grujičc ${ }^{4}$
}

\begin{abstract}
Summary
The authors of this paper emphasise the analysis of the state and investment in systems for protection against waters in the previous, transitional, period, the consequences of the 2014 floods, and financing the reconstruction of damaged water facilities as well as the legislative and institutional framework for the policy of protection against waters in the pre-accession period. The results of the analysis imply insufficient investments in watercourse regulation and maintenance and improvement of facilities for protection against floods from surface water, groundwater, erosion and torrents in the transition period. In the past years, especially after the last-year's floods, there is an intensification of activities on recovery, reconstruction and construction of water management infrastructure for protection against waters. There is also intense work on harmonising the legislation with the corresponding legislation of the EU and fulfilling the obligations from the signed international conventions in this area.
\end{abstract}

Key words: floods, water management infrastructure, protection measures, risk management.

JEL: $Q 54$

\section{Introduction}

Among natural disasters, with serious risks for people and their activities, floods have been the most common in terms of frequency, their threat level and the damage they cause; accordingly, they deserve special attention (Gavrilović Lj, et al., 2012). Floods

1 This paper is part of research on the project No 46006: "Sustainable agriculture and rural development in the function of achieving the strategic goals of the Republic of Serbia in the Danube region", financed by the Ministry of Education, Science and Technological Development of the Republic of Serbia.

2 Nataša Kljajić Ph.D., Research Associate, Institute of Agricultural Economics, Volgina street no. 15, 11060 Belgrade, Serbia, E-mail: natasa k@iep.bg.ac.rs

3 Vesna Popović, Ph.D., Principal Research Fellow, Institute of Agricultural Economics, Volgina street no. 15, 11060 Belgrade, Serbia, E-mail: vesna p@iep.bg.ac.rs

4 Biljana Grujić, B.Sc., Research Assistant, Institute of Agricultural Economics, Volgina street no. 15, 11060 Belgrade, Serbia, E-mail: biljana_g@iep.bg.ac.rs

EP 2016 (63) 2 (585-600) 
are, after draught, the most common and widespread natural disaster. Floods affect a large number of people and inflict great material damage, much larger than all other kinds of natural disasters. They can destroy entire cities and send thousands of people to search for shelter. Leading a constant battle against floods, people view them with anxiety and fear. Almost every year, the rivers leave their beds and flood smaller or larger areas, thus threatening both people and material goods.

Floods are a natural phenomenon, but humans who have, through their actions, intensified climatic changes and harmed the environment, have certainly contributed to their frequency in the past years. Since 1980, there were 325 major floods in Europe, 200 of which from the year 2000 to today. Land use change is often mentioned as a reason for this. In urban surroundings, where soil sealing is common, there is a distinct threat from more frequent and intense natural disasters followed by heavy precipitation that exceeds the capacity of the rain sewer and jeopardise the water quality in the aqueducts. The frequency and intensity of this precipitation is connected to the disturbance in the hydrological cycle caused by global warming (EEA, 2012). Among natural hazards with serious risks for people and their activities, torrential (flash) floods are the most common hazard in Serbia and the most significant regarding ' huge material damage and loss of human lives. The frequency of these events, their intensity and diffusion in the whole country make them a permanent threat with severe consequences to environmental, economic and social spheres (Ristic, et al, 2012.a).

Appearance of torrential floods is mostly out of man control. Man made hazard could be increased by irresponsible activities concerning land use or decreased with preventive activities: spatial planning in endangered watersheds; afforestation of bare lands, amelioration of degraded forests, meadows and pastures; appropriate agricultural techniques; application of agroforestry; erosion control measures and torrent training works (Ristic et al., 2012b).

Floods are directly influenced by precipitation, the state of the water level in the main stream during the flood wave, ice jams, flow meanders, active landslides and the coincidence of high levels of water from tributaries and the main river flow, (Gavrilović, 1981).

Precipitation has the highest significance for the occurrence of floods. Rain immediately leads to an increase in water level, while snow increases the water level when it melts. The height of the flood wave depends on the amount of precipitation and the size of the river basin, while intensity is of less significance. Pouring rain is short lasting and affects smaller areas, while long lasting rain affects the whole basin or large portions of it; they saturate the land with water and lead to growth in water levels in the whole river network. That is when there occurs a large flood wave and floods of catastrophic proportions in the valley of the main river. Snow cover can contain large amounts of water, and snow precipitation can only lead to an increase in the water level after the snow melts. The unfavourable circumstances are, though, that the snow melting usually coincides with the oncome of heavy spring and late autumn rains. In this case, there is an increase in water level and the formation of a flood wave, which lasts longer on large and midsized rivers. During especially cold winters, 
ice jams, which can reach significant thickness, can form on rivers. In the early spring, when the ice melts, icy corks can form in the riverbed, in the form of bridges, shelves or river meanders, the icy barrier becomes thicker and thicker, and up-flow, the river turns into a lake and then floods the surrounding areas. This type of floods used to occur on the Velika Morava, Tisa and Danube rivers, before the construction of accumulation.

Indirect contribution to floods is also made by the shape and size of the basin, density of the river network, relief, water-saturation in the soil, state of underground water levels, degree of forestation and the manner of tilling the agricultural land in the basin (Gavrilović, 1981). The occurrence of floods is also influenced by the geological composition of the terrain in the basin, the pedological structure, degree of cultivation in the observed area, canal construction and other factors. Consequences (damage) that occur from floods are diverse, but the greatest and most difficult consequence is the loss of human lives, which are un-recoupable. For the threatened population, the most difficult consequences are the destroyed homes. The outpouring of sewers, aqueduct damage and drinking water pollution in the settlements can be followed by the occurrence of various epidemics and health threats for many people. The river valleys house the largest agricultural areas and the most productive soil. Floods completely destroy crops, and in some better cases their yields are reduced. Traffic infrastructure can also suffer from floods. They tear down bridges, embankments, roads and railways, they can cover them or cause them to slide in places where the conditions of the natural relief are disturbed. Due to flooding in industrial facilities, production discontinuance or material loss can occur, and in the case of chemical industry or industry of dangerous substance production, there is also the danger of water pollution with toxic elements (Gavrilović, 1981).

On the other hand, we must not forget that floods are a part of the normal functioning of the ecosystem of flood forests and swamps. These represent natural mechanisms of flood protection by slowing down and disburdening the river flows. These ecosystems are jeopardised by work on regulation and the construction of water facilities as well as systems for defence against water. The measures for preservation of the so-called "green infrastructure", especially those connected to natural water retention (NWRM) have gained a significant place in the plans for water basin management and management of flood risk, and they will also have financial priority in the following plan period (EC, 2012; ICPDR, 2014a; ICPDR, 2014b).

\section{Flooded areas and areas protected against floods in the Republic of Serbia, 2009-2013}

According to data from the Statistical Office of the Republic of Serbia, in the period of 2009-2013, every year between 5 and 117 thousand ha was flooded, of which between 4 and 98 thousand ha was utilised agricultural land. In this period, between 88 and 448 settlements were endangered yearly, between 118 and 360 industrial facilities, 9 and $50 \mathrm{~km}$ of railway lines, as well as between 81 and $763 \mathrm{~km}$ of roads (Table 1.). 
Table 1. Flooded areas and facilities in the Republic of Serbia, 2009-2013

\begin{tabular}{|c|r|r|r|r|r|r|}
\hline Year & $\begin{array}{c}\text { Total flooded } \\
\text { area, thous. ha }\end{array}$ & $\begin{array}{c}\text { Utilised } \\
\text { agricultural } \\
\text { area, thous. ha }\end{array}$ & $\begin{array}{c}\text { Settlements, } \\
\text { number }\end{array}$ & $\begin{array}{c}\text { Industrial } \\
\text { facilities, } \\
\text { number }\end{array}$ & $\begin{array}{c}\text { Railway lines, } \\
\text { km }\end{array}$ & Roads, km \\
\hline 2009 & 23 & 88 & 313 & 171 & 15 & 51 \\
\hline 2010 & 117 & 98 & 448 & 360 & 44 & 763 \\
\hline 2011 & 85 & 76 & 303 & 235 & 9 & 464 \\
\hline 2012 & 65 & 55 & 206 & 118 & 14 & 547 \\
\hline 2013 & 5 & 4 & 114 & & 634 \\
\hline
\end{tabular}

Source: SORS, Statistical Yearbook, 2012, 2014.

According to the Spatial Plan for the Republic of Serbia 2010-2021 (Official Gazette of the RS, 88/2010), around 2.08 million ha of land should be protected from flooding by surface water, groundwater, mostly in Vojvodina. In the absence of the existing protection systems, around 1.29 million ha in Vojvodina as well as the valley of the great rivers in central Serbia and Kosovo would be threatened by the one-hundredyear flood. There we can find high quality agricultural land, large industrial systems and developed transport infrastructure. Categories I-III erosion threatens $36 \%$ of the country's territory. Excessive erosion (category I) is especially present in the basins of Južna Morava, Pčinja and Beli Drim.

Protection against the detrimental effects from waters also includes measures and work on protection from surface water, groundwater, and protection against ice, protection against erosion and torrents and the recovery from such water effects. It is conducted using systems for protection against external waters - water facilities for watercourse regulation and embankments, erosion and torrents and drainage systems - water facilities for protection against the detrimental effects from internal waters.

The total area defended from floods in the period of 2009-2013 moved in the interval from 995 thousand ha in 2013 to 2 million ha in 2009 (of which utilised agricultural land was between 855 thousand ha and 1.9 million ha). The number of settlements defended from floods was between 563 (2009) and 716 (2012). Every year, between $553 \mathrm{~km}$ and 1,039 km of railway lines and between 2,304 km and 4,832 km of roads were defended from floods. The length of flood defence embankments in 2013 was 2,828 km (Table 2.).

Table 2. Areas and facilities protected against floods in the Republic of Serbia, 2009-2013

\begin{tabular}{|c|r|r|r|r|r|r|r|}
\hline Year & $\begin{array}{c}\text { Total area } \\
\text { protected } \\
\text { against floods, } \\
\text { thous. ha }\end{array}$ & $\begin{array}{c}\text { Utilised } \\
\text { agricultural } \\
\text { area, } \\
\text { thous. ha }\end{array}$ & $\begin{array}{c}\text { Number of } \\
\text { settlements }\end{array}$ & $\begin{array}{c}\text { The number } \\
\text { of industrial } \\
\text { facilities }\end{array}$ & $\begin{array}{c}\text { Railway } \\
\text { lines, } \mathbf{k m}\end{array}$ & Roads, km & $\begin{array}{c}\text { Length of } \\
\text { embank } \\
\text { ments, km }\end{array}$ \\
\hline 2009 & 1,999 & 1,869 & 563 & 442 & 983 & 2,558 & 3,032 \\
\hline 2010 & 1,959 & 1,763 & 657 & 498 & 862 & 4,810 & 3,299 \\
\hline 2011 & 1,958 & 1,709 & 644 & 481 & 1,039 & 4,832 & 3,446 \\
\hline 2012 & 1,469 & 1,260 & 716 & 586 & 711 & 2,411 & 3,458 \\
\hline 2013 & 995 & 855 & 603 & 506 & 553 & 2,304 & 2,828 \\
\hline
\end{tabular}

Source: SORS, Statistical Yearbook, 2012, 2014. 
Besides embankments, protection systems also include around 1,200 km of regulated flow and canal systems and 29 accumulations, which alleviate the flood waves. Defence line systems along the three large rivers, Danube, Sava and Tisa, including the hydro-system Danube-Tisa-Danube (HS DTD) protect more than 852 thousand ha. The situation is significantly less favourable on the banks of Drina and Velika Morava and Južna Morava. In the Drina basin, 65 thousand ha are threatened, and just as much land in the basin of Velika Morava, where adequate systems only defend somewhat more than 23 thousand ha, while protection against the one-hundred-year floods in the basin of Južna Morava is only provided for about 4.6 thousand ha of about 39 thousand ha threatened land (Đorđević, 2009).

According to regional models of climate changes, an increased frequency and intensity of torrential floods is expected in the near future. Anti-erosion work was most intensive in the period of 1961-1988, when, besides the afforestation and melioration of forests, meadows and pastures, there was built around $14,000 \mathrm{~km}$ of rows, walls and terraces on the erodible terrains, as well as 3,200 barriers on the torrential flows, for controlling deep erosion, riverbed stabilisation and reducing deposit transportation (Group of authors, 2003).

Land drainage in the Republic of Serbia in the period of 2009-2013 was conducted on an area of 1.9 million ha (2009) to 2.2 million ha (2011). The statistics in 2009 have registered $5,093 \mathrm{~km}$ of drainage canals, and in $20135,601 \mathrm{~km}$. There were 223 pumping stations operating within these systems in the year of $2013^{5}$ (Đorđević, 2009) (Table 3.).

Table 3. Drainage in the Republic of Serbia, 2009-2013

\begin{tabular}{|c|r|r|r|}
\hline Year & $\begin{array}{c}\text { Total area covered by drainage } \\
\text { systems, thous. ha }\end{array}$ & $\begin{array}{c}\text { Drainage canals, } \\
\mathbf{~ k m}\end{array}$ & Number of pumping stations \\
\hline 2009 & 1,917 & 5,093 & 226 \\
\hline 2010 & 1,954 & 5,488 & 231 \\
\hline 2011 & 2,240 & 5,336 & 249 \\
\hline 2012 & 2,156 & 5,575 & 231 \\
\hline 2013 & 2,132 & 5,601 & 223 \\
\hline
\end{tabular}

Source: SORS, Statistical Yearbook, 2012, 2014.

Investment in the maintenance and development of water management infrastructure could only be characterised as "acceptable" until the 1980ies (Group of authors, 2003). During the transitioning period that followed and still lasts today, there was a sudden drop in budget financing of water management, which left big consequences on the functioning of the system for protection against waters.

According to the initially envisaged financial means for the year of 2014 of public company for water management (PCWM) "Srbijavode", the programme for maintenance of water facilities for protection against the detrimental effects from waters was reduced to $38 \%$ of

5 According to available data from 2009, around $2.08 \times 10^{6}$ ha was under some of the 400 drainage systems, where 210 major pumping stations were operational, with an installed capacity of 543 $\mathrm{m}^{3} / \mathrm{s}$. 
the needed scope, while the level of investment into maintenance of dams with accumulation does not ensure the functional security of these capital facilities.

It is estimated that around 1.5 billion RSD annually, i.e. 7.5 billion RSD in total should be provided for the protection of the most threatened areas in Serbia in the next five years. The mentioned assets would ensure the necessary degree of maintenance and functionality of the built water facilities for protection against waters, enhancing the existing facilities in accordance with the predetermined priorities, and technical documentation for the new investment cycle in the area of protection against waters (PCWM "Srbijavode", 2014).

The lack of financial assets in the budget of the Republic is reason enough for insufficient maintenance of facilities for protection against floods in the past twenty years in the territory of AP Vojvodina as well, according to assessments from the PCWM "Vojvodina vode". Thirty to seventy percent of work on water system maintenance was done in accordance to the current standards and criteria, which resulted in poor functional state of water facilities, decrease in system efficiency up to $50 \%$, i.e. inadequate degree of flood protection of people and goods in AP Vojvodina (PCWM "Vode Vojvodine", 2014).

\section{Floods in Serbia in 2014 - damage and reconstruction of damaged water facilities}

Serbia was hit by floods of great proportions in May 2014, caused by heavy rain that went on for 48 hours. The damage caused by the floods in the territory of 24 municipalities was estimated to be 1,525 million EUR (where the value of destroyed properties was 885 million EUR, and loss in production about 640 million EUR), which represents 3\% of the country's GDP ${ }^{6}$ (The Government of the Republic of Serbia, 2014). The greatest loss and damage was noted in the production sector (agriculture, manufacture, trade, tourism, mining and energetics), in the amount of 1,064 million EUR (70\%). It is estimated that 51,800 workplaces will be lost before time due to cessation in production activities in the threatened municipalities, with proportional decrease in household income. In the sectors of accommodation, education, health and culture, the damage amounts to 242 million EUR (16\%). The damage on infrastructure is estimated at 192 million EUR (12\%), while in the area of environment protection and multipurpose facilities, the damage lies at around 28 million EUR (2\%) (Table 4.).

Table 4. Summary of estimated damages and losses caused by the disaster, 2014

\begin{tabular}{|l|l|r|r|r|}
\hline \multicolumn{2}{|c|}{} & \multicolumn{3}{|c|}{ Disaster Effects, mIn EUR } \\
\cline { 3 - 5 } \multicolumn{2}{c|}{} & \multicolumn{1}{|c|}{ Damage } & Losses & Total $^{*}$ \\
\hline Social & Housing & $\mathbf{2 3 4 . 6}$ & $\mathbf{7 . 1}$ & $\mathbf{2 4 1 . 7}$ \\
\hline & Education & 227.3 & 3.7 & 230.9 \\
\hline & Health & 3.4 & 0.1 & 3.5 \\
\hline & 3.0 & 2.7 & 5.7 \\
\hline
\end{tabular}

6 If we consider the municipalities not included in the assessment, but which were still affected by the floods to a lesser degree, then the estimated damage goes up to 1.7-1.8 billion EUR. 


\begin{tabular}{|c|c|c|c|c|}
\hline & & \multicolumn{3}{|c|}{ Disaster Effects, mIn EUR } \\
\hline & & Damage & Losses & Total $^{k}$ \\
\hline & Culture & 1.0 & 0.6 & 1,6 \\
\hline \multirow[t]{6}{*}{ Productive } & & 516.1 & 547.6 & $1,063.6$ \\
\hline & Agriculture & 107.9 & 120.1 & 228.0 \\
\hline & Manufacturing & 56.1 & 64.9 & 121.0 \\
\hline & Trade & 169.6 & 55.2 & 224.8 \\
\hline & Tourism & 0.6 & 1.6 & 2.2 \\
\hline & Mining and energy & 181.9 & 305.8 & 487.7 \\
\hline \multirow[t]{4}{*}{ Infrastructure } & & 117.3 & 74.8 & 192.1 \\
\hline & Transport & 96.0 & 70.4 & 166.5 \\
\hline & Communications & 8.9 & 1.1 & 10.0 \\
\hline & Water and sanitation & 12.4 & 3.2 & 15.7 \\
\hline \multirow[t]{3}{*}{ Cross cutting } & & 17.2 & 10.6 & 27.9 \\
\hline & Environment & 10.6 & 10.1 & 20.6 \\
\hline & Governance & 6.7 & 0.6 & 7.2 \\
\hline Total & & 885.2 & 640.1 & $1,525.3$ \\
\hline
\end{tabular}

Source: The Government of the Republic of Serbia (2014): Serbia Floods 2014, Belgrade (http:// ec.europa.eu/enlargement/pdf/press_corner/floods/20140715-serbia-rna-report.pdf)

Floods have, most of all, damaged the energy sector, which took more than 210 million EUR to reconstruct, while the damage in accommodation is estimated at 227 million EUR. Water and landslides have destroyed more than 400 accommodation units, while approximately 17,000 flats and accommodation units have suffered partial damage. Another 74 facilities of healthcare took damage, including emergency facilities, health offices and clinics, as well as 35 pre-school and school facilities. The total amount of assets for the recovery and reconstruction is estimated at 1,346 million EUR, where 403 million EUR goes to recovery and 943 million EUR is for reconstruction (Table 5.).

Table 5. Summary of estimated recovery and reconstruction needs

\begin{tabular}{|c|c|c|c|}
\hline \multirow{2}{*}{ Sector } & \multicolumn{3}{|c|}{ Post-Disaster Needs, mln EUR } \\
\hline & Recovery & Reconstruction & Total $^{*}$ \\
\hline Agriculture & 40.8 & 111.4 & 152.1 \\
\hline Manufacturing & 16.6 & 53.3 & 69.8 \\
\hline Trade & 12.9 & 144.0 & 157.0 \\
\hline Tourism & 0.5 & 0.7 & 1.2 \\
\hline Mining and energy & 211.8 & 202.0 & 413.8 \\
\hline Housing & 58.8 & 204.5 & 263.3 \\
\hline Education & 2.0 & 4.3 & 6.3 \\
\hline Health & 2.7 & 4.4 & 7.1 \\
\hline Culture & 0.1 & 1.2 & 1.3 \\
\hline Transport & - & 128.2 & 128.2 \\
\hline Communications & - & 12.6 & 12.6 \\
\hline
\end{tabular}




\begin{tabular}{|l|r|r|r|}
\hline Water and sanitation & 3.5 & 24.0 & 27.5 \\
\hline Environment & 2.8 & 38.7 & 41.5 \\
\hline Governance & 2.3 & 14.1 & 16.4 \\
\hline Employment & 46.4 & & 46.4 \\
\hline Gender & 2.0 & & 2.0 \\
\hline Totals & $\mathbf{4 0 3 . 0}$ & $\mathbf{9 4 3 . 5}$ & $\mathbf{1 , 3 4 6 . 5}$ \\
\hline
\end{tabular}

Source: The Government of the Republic of Serbia (2014): Serbia Floods 2014, Belgrade (http:// ec.europa.eu/enlargement/pdf/press_corner/floods/20140715-serbia-rna-report.pdf)

The Law on Post-Flood Rehabilitation in the Republic of Serbia (Official Gazette of the RS, 75/2014) regulates the recovery from the consequences of the floods, i.e. landslide activation in areas affected by the floods that took place in May 2014 in Serbia. The recovery in areas affected by the floods is taking place in accordance with Government Recovery Programmes, which lay down the measures and criteria for providing assistance or post-flood rehabilitation and recovery criteria, measures and procedures in individual fields and in a specified territory. The funds for the rehabilitation from the consequences of floods and/or activated landslides in the sense of this law are provided from: the budget of the Republic of Serbia, the budget of the autonomous province, the budget of the units of local self-government, donations, contributions and gifts, borrowings, receipt from the sale of financial assets, financial assistance of the European Union, funds of public enterprises and other forms of organisation founded by the Republic of Serbia, autonomous province, or local self-government unit, and other sources in accordance with the law. Recovery and reconstruction will take place in the period of 2014-2016 (Table 6.).

Table 6. Time schedule of recovery and reconstruction requirements, 2014-2016

\begin{tabular}{|l|r|r|r|r|}
\hline \multirow{2}{*}{ Needs } & $\mathbf{2 0 1 4}$ & \multicolumn{2}{c|}{$\mathbf{2 0 1 5}$} & \multicolumn{2}{c|}{$\mathbf{2 0 1 6}$ Total $^{*}$} \\
\cline { 2 - 6 } & \multicolumn{4}{|c|}{ Mln EUR } \\
\hline Recovery & 236.1 & 146.4 & 20.5 & 403.0 \\
\hline Reconstruction & 592.7 & 290.5 & 60.3 & 943.5 \\
\hline Totals & $\mathbf{8 2 8 . 9}$ & $\mathbf{4 3 6 . 8}$ & $\mathbf{8 0 . 8}$ & $\mathbf{1 , 3 4 6 . 5}$ \\
\hline
\end{tabular}

Source: The Government of the Republic of Serbia (2014): Serbia Floods 2014, Belgrade (http:// ec.europa.eu/enlargement/pdf/press_corner/floods/20140715-serbia-rna-report.pdf)

The government programme for recovery of damaged water facilities ${ }^{7}$ predicts taking measures of urgent interventions (temporary closing of embankment perforations and critical damage on water facilities) and urgent work on recovery of water facilities for regulation of watercourses, water facilities for protection against floods, erosion and torrents and water facilities for drainage, with providing adequate documentation, in the total value of 3,146.9 million RSD (PWMC "Srbijavode" 1,687 million RSD, PWMC

7 The Act on Determining a Government Programme for Recovery of water facilities for watercourse regulation, water facilities for protection against floods, erosion and torrents, and water facilities for drainage. 
"Vode Vojvodine" 400.3 million RSD and PWMC "Beogradvode" 1,059.6 million RSD) (Official Gazette of RS, 86/2014, 103/2014). It was predicted that urgent interventions should be realized by the end of October 2014, and urgent work on recovery of the mentioned water facilities by July $15^{\text {th }}, 2015$. The investor is the Republic of Serbia.

The Government of Serbia in December 2014 adopted a national program for the management of risks from natural disasters, which will be implemented in cooperation with the World Bank, the UN and the EU. For the implementation of prevention programs has so far provided over 70 million euros. The value of donations to the sources of funding are (http://www.obnova.gov.rs/uploads/useruploads/Documents/Kancelarija-za-pomocpoplavljenih-podrucja-infograf-15-04-2016-srb.pdf):

- $\quad$ For the agriculture sector of the identified 11 million, EU financed 8 million euro ${ }^{8}$;

- FAO, in cooperation with the Ministry of Agriculture and Environmental Protection organized the distribution of seeds, fertilizers (61 million RSD) and fuel (almost 65 million RSD) for small farms;

- $\quad$ In cooperation with the World Bank were provided subsidies to farmers in the amount of 35 million dollars.

\section{Financing the work and activities on protection against waters in the year of 2015}

The budget fund for waters of the Republic of Serbia ${ }^{9}$ intends 2,033.8 million RSD for watercourse regulation works and protection against the detrimental effects from waters in the year of 2015 (Official Gazette of RS, 142/2014). An amount of 1,969.3 million RSD is meant for financing new work and the rest for covering the expenses of work done in 2014. The distribution of assets is performed by an annual programme of water management (Official Gazette of RS, 21/2015). Most assets will be used to maintaining water facilities for watercourses regulation, water facilities for protection against floods, erosion and torrents (805.2 million RSD), and maintaining water facilities for drainage (409.1 million RSD). Over $90 \%$ of these investments represent regular maintenance of the mentioned facilities, while the assets meant for investment maintenance are particularly modest, as well as assets for construction and reconstruction of water facilities for watercourses regulation and water facilities for protection against floods, erosion and torrents (60 million RSD) and for protective, biological and biotechnical works (45 million RSD). The recovery of water facilities for watercourses regulation, water facilities for protection against floods, erosion and torrents and water facilities for drainage should receive 431 million RSD and conducting

8 Were donated aid packages in the form of: of seedlings, domestic animals, feed for farm animals, equipment etc.

9 The total amount of assets in the Budget Fund for Waters (evidential account within the Treasury General Ledger, in the heading of The Ministry of Agriculture and Environment Protection of the Budget of the Republic of Serbia) for the year of 2015 is determined at 3,120 million RSD, where budget revenues participates with 2,320 million RSD and donations from international organisations with 800 million RSD.

EP 2016 (63) 2 (585-600) 
defence against floods and ice another 170 million RSD. The rest of the assets will cover expenses of project planning (110 million RSD) and maintaining expert surveillance over conducting work on recovery and maintenance of riverbeds and protective biotechnical work on the territory of the City of Belgrade (3.5 million RSD).

The budget fund for waters of the AP Vojvodina in 2015 finances works on regulation, use and protection of waters on the territory of the AP Vojvodina, as defined by the business programme of PWMC "Vode Vojvodine", in an amount of 2,476 million RSD (Official Gazette of APV, 54/2014). According the data from the Business Programme of PWMC "Vode Vojvodine" for the year of 2015, for regular maintenance and functioning of water facilities in 2015 from the Province Fund is allocated 1,379.2 million RSD of required 4,459.5 million RSD, as follows:

- Regular maintenance and functioning of the drainage systems received 1,075 million RSD out of the needed 3,566.3 million RSD (30.1\%),

- Regular and urgent maintenance and enhancement of protective facilities, protection against detrimental effects from waters and defence against floods received 132 million RSD out of the needed 606.8 million RSD (21.8\%), and

- Maintenance of the HS DTD received 172.2 million RSD out of the needed 286.4 million RSD (60.1\%).

Additional means are provided from the Programme of Regulation, Protection and Use of Agricultural Land in APV, other sources of financing from provincial level, and other sources (RS, municipalities, own assets and EU funds). Still, even with these additional assets, the maintenance of the mentioned water facilities and systems still lacks 961.5 million RSD, i.e. the maintenance is performed at a degree of $78.4 \%$ (PWMC "Vode Vojvodine", 2014).

\section{Measures of defence against floods - legislative and institutional framework}

The measures of integral protection against the detrimental effects from waters are divided into investment measures (hydro-engineering) and non-investment. The investment measures include active measures (building accumulations, retentions and diversion canals) and passive measures of protection against floods (building embankments, bank revetments and protective cassettes, and regulation of riverbeds).

Active measures of flood protection have a goal of reducing unfavourable characteristics of large waters. For example, up-flow accumulations, which are some of the most important active measures, serve to reduce the flow of large waters. Active measures are not dominant in Serbia, considering that the possibilities for building significant accumulations for levelling large waters on large water flows are limited.

Passive measures of protection from floods are used to prevent direct overflow of large waters out of the riverbed. The most important and most common passive measures include coastal embankments built along the riverbed. In Serbia, the degree of construction 
of embankments alongside the smaller rivers is not satisfying, which is why floods are relatively common. Considering the natural characteristics of the waters, and the limited possibility of constructing significant accumulations for levelling large waters, the systems of defence in key flood prone areas in Serbia (Vojvodina, Mačva, Srem, Lower Posavina with the City of Belgrade, Pomoravlje) must still rely on passive measures, which have to be adjusted to the realistic conditions and needs.

Non-investment measures of flood protection include administrative, regulative and institutional measures that preventively reduce the current and future damage from floods or ensure adequate defence from floods through preventive action or good organisation. Non-investment measures are a significant addition to active and passive measures of flood defence (Petković, 2006 and Kljajić et al., 2012).

Preventive and operative non-investment measures are directed at flood danger combat and reducing the negative consequences in all phases of flood defence. Regulative and institutional measures define the manner of land use in the flood threatened area (zoning the terrain according to the degree of threat, regulations on the purpose of the threatened terrain, civil engineering regulations). Measures of solidarity for mitigating the consequences of floods have a goal to reduce the damage that appears during and after the floods, due to disturbances in the social and economic life (recovery and reconstruction, insurance from the consequences of the floods etc.) Informing and educating the population are necessary for the efficient conduction of flood defence (Varga, Babić-Mladenović, 2001).

Due to the described state and need for harmonising the legislation on flood protection with that of the EU, in future activities special attention should be dedicated to:

- permanent studying of the state, conditions and measures of flood defence,

- $\quad$ systematic and high-end maintenance, reconstruction and operation control of the existing facilities,

- non-investment protection measures,

- adjusting the newly appeared conditions in accordance with the principles of sustainable development,

- $\quad$ harmonising the legislation with the EU acquis and intensifying international cooperation.

Managing risk of detrimental effects from waters is the foundation of successful protection against floods, erosion and torrents and according to the Law on Waters (Official Gazette of RS, 30/2010, 93/2012) it includes: the preliminary assessment of flood risk ${ }^{10}$, making and conducting the plans on flood risk management, general and operative plans of flood defence, conducting regular and urgent flood defence, conducting defence against ice on the watercourses and protection against erosion and torrents.

10 The preliminary flood risk assessment from 2011 defined 99 areas of potential significant flood risk on the territory of the Republic of Serbia.

EP 2016 (63) 2 (585-600) 
The EU Floods Directive (Directive 2007/60/EC of the European Parliament and of the Council on the assessment and management of flood risks. OJ L288, 6.11.2007.) regulates the construction of flood risk management plans on the river basin level (FRMPs), predicted by the 2000 Water Framework Directive - WFD (Directive 2000/60/EC of the European Parliament and of the Council establishing a framework for Community action in the field of water policy. OJ L327, 22.12.2000.) starting from the next RBMPs plan cycle in 2015. The Flood Risk Management Plans must be considered when making inter-sector plans on risk management and plans on natural disaster risk management. By ensuring the due attention to consequences of climate changes and measures of adaptation, we improve spatial planning and land management (EC, 2012).

Serbia, as Contracting Party of the Convention on cooperation for the protection and sustainable use of the River Danube (Official Gazette of FRY - International Treaties, 2/2003), has committed itself to the development of the co-ordinated international River Basin Management Plan for the Danube River Basin as requested by the EU Water Framework Directive. On that account, it has participated in the development of the EU Danube River Basin Management Plan 2009-2015 (DRMB) and its Update 2015 as well as in the development of the 1st DRB Flood Risk Management Plan. Plan for flood risk management in the Danube basin focuses on prevention, protection and preparedness, including flood forecasts and early warning systems (ICPDR, 2014a). In the draft of the updated DRBM Plan, there is emphasis on the need for coordinating flood risk management and river basin management planning ${ }^{11}$ in order to increase the efficiency of the implementation of measures and improve resource efficiency (ICPDR, 2014b).

As an EU-candidate, Serbia is intensely working on transposing the EU acquis into domestic legislative. Most of the Water Framework Directive and the Floods Directive has been transposed through the Law on Waters and the following subordinate regulations, and a complete transposition is planned until the end of 2017 (WFD), i.e. mid 2018 (all relevant EU regulations). The passing of the Danube River Basin Management Plan with Programme of measures is expected in middle 2015, and the preparation of flood hazard maps and their publication towards the end of 2018 (The Government of RS, 2014a).

In accordance with the EU recommendations and practice, following measures and activities for flood risk management are included in the National Programme for Natural Disaster Risk Management (The Government of RS, 2014b):

- identification and monitoring the flood risks and building the systems of early warning and preparedness,

- structural (infrastructural and institutional flood defence interventions) and nonstructural measures of flood risk reduction (flood risk incorporation into the land use plans and urban planning, improvement of the engineering regulations),

- establishment of institutions and financing strategies,

11 The achievement of synergies in practice needs to be ensured mainly at the national level, as the implementation of measures envisaged by RBM Plan and FRM Plan is a national task. 
- efficient recovery from floods.

\section{Conclusion}

Flood defence is an important segment of measures and activities connected to river basin management. During the previous development of this subsector of water management, the principle of flood combat was principally used in Serbia. It included construction of significant and expensive investment facilities (dams, accumulations, embankments, watercourses regulation, diversion canals, etc.) in order to ensure safety for people and material goods situated in the flood risk areas.

Defence against the detrimental effects from waters in the coming times must be based on the principles of sustainable development (the consciousness that there is no absolute flood defence, but that floods are something we have to live with, adjusting the needs of society and the environment), integrality (ensuring flood protection by combining investment and non-investment measures) and coordination (harmonised action of authorised organisations on a local, national and international level) with respect to the current state of the flood protection system and the economic strength of the society.

An adequate combination of non-investment and investment (hydro-engineering) work and measures at the river basin level should provide a good solution to integrated regulation and protection of the flood risk areas in Serbia. On large river basins, flood protection will still rely on hydro-engineering facilities, but the protection measures must also be based on flood hazard maps and flood risk maps, in order to adjust the activities with the specificities of a defined flood risk area. In the basins of smaller and mid-ranged rivers, non-investment measures should become more significant, as they influence the reduction of damage, whether by preventive action, or by good organisation in flood defence. In the following period, the main emphasis will be on increasing the degree of flood protection in large agglomerations (Belgrade, Novi Sad), industrial centres, and thermo-energetic capacities and increasing the retention capacities in the basins by building cassettes, accumulations etc.

It is expected that the mentioned measures and activities should be defined at the level of areas of potential significant flood risk and based on flood hazard maps and flood risk maps. As such, they will be included in flood risk management plans, which are, according to the Law on Waters, made for the territory of the Republic of Serbia and water areas. In the domain of international cooperation, emphasis lies on participation in making and implementing flood risk management plans, coordinated with river basin management plans, in accordance with the EU Floods Directive.

By reducing the risk of floods and other natural disasters, we influence the increase of competitiveness of Serbia on the international markets. 


\section{Literature}

1. Directive 2007/60/EC of the European Parliament and of the Council on the assessment and management of flood risks. OJ L288, 6.11.2007.

2. Directive 2000/60/EC of the European Parliament and of the Council establishing a framework for Community action in the field of water policy. OJ L327, 22.12.2000.

3. Đorđević, D. (2009): Vodoprivreda $i$ vodoprivredna infrastruktura, Strategija prostornog razvoja Republike Srbije, Studijsko-analitička osnova, Institut za arhitekturu i urbanizam Srbije, Beograd, Srbija

4. European Commission (2012): A Blueprint to Safeguard Europe's Water Resources, Brussels, COM(2012) 673 final.

5. European Environment Agency - EEA (2012): European waters - current status and future challenges, Synthesis, EEA Report, No 9/2012.

6. Gavrilović, L. M. (1981): Poplave u SR Srbiji u XX veku - uzroci i posledice, Beograd: Srpsko geografsko društvo, Special edition, book 52.

7. Institut za vodoprivredu «Jaroslav Černi»- IJČ. (2003): Studija održivog razvoja vodoprivrede Republike Srbije.

8. International Commission for the Protection of the Danube River - ICPDR (2014a): Flood Risk Management Plan for the Danube River Basin District.

9. International Commission for the Protection of the Danube River - ICPDR (2014b): The Danube River Basin District Management Plan - Update 2015. Draft, December 2014.

10. Gavrilović Ljiljana, Milanović Pešić Ana, Urošev Marko (2012): A hydrological analysis of the greatest floods in Serbia in the 1960 - 2010 period". Carpathian Journal of Earth and Environmental Sciences, November 2012, vol. 7, no. 4, pp. 107 - 116.

11. JVP "Srbijavode” (2014): Program poslovanja za 2014. godinu.

12.JVP "Vode Vojvodine" (2014): Godišnji program poslovanja za 2015. godinu.

13. Kljajić Nataša, Arsić Slavica, Mijajlović Nada (2012): “Zemljište kao ekološki factor poljoprivredne proizvodnje". Tranzicija vol. 14, no 29, pp. 38-47.

14. Petković, S. (2006): Izveštaj o korišćenju voda, zaštiti voda i zaštiti od voda u 16 opština/ gradova Srbije, CeSID, Beograd.

15. Ristic, R., Kostadinov, S., Abolmasov, B., Dragicevic, S., Trivan, G., Radic, B., Trifunovic, M., Radosavljevic, Z. (2012a): "Torrential floods and town and country planning in Serbia “, Natural Hazards and Earth System Sciences no. 12, pp/ 23-35.

16. Ristić, R., Kostadinov, S., Radić, B., Trivan, G., Nikić, Z. (2012b): ,, Torrential floods In Serbia - man made and natural hazards ", 12th Congress INTERPRAEVENT 2012 - Grenoble / France Conference Proceedings (available at: www.interpraevent. at).

17. The Government of the Republic of Serbia. (2014): Serbia Floods 2014, Serbia Recovery Needs Assessment Report: The European Union, the United Nations and the World Bank (available at: http://ec.europa.eu/enlargement/pdf/press_corner/floods/ 
20140715-serbia-rna-report.pdf).

18. The World Bank (2014): Irrigation and Drainage Rehabilitation Project (Serbia), Implementation completion and results report (IBRD-74670 IDA-41050)No: ICR00003127, October 22, 2014.

19. Varga, S., Babić-Mladenović, M. (2001): Zaštita od poplava u Srbiji-novi pristup, U: Upravljanje vodnim resursima Srbije, Beograd, Institut za vodoprivredu Jaroslav Černi.

20.Vlada Republike Srbije, Kancelarija za evropske integracije (2014a): Nacionalni program za usvajanje pravnih tekovina Evropske unije 2014-2018.

21. Vlada Republike Srbije, Kancelarija za pomoć i obnovu poplavljenih područja (2014b): Nacionalni program upravljanja rizikom od elementarnih nepogoda (available at: http://www.obnova.gov.rs/cirilica/news/article/vode)

22.http://www.obnova.gov.rs/uploads/useruploads/Documents/Kancelarija-za-pomocpoplavljenih-podrucja-infograf-15-04-2016-srb.pdf 


\title{
ZAŠTITA OD ŠTETNOG DEJSTVA VODA U REPUBLICI SRBIJI ${ }^{12}$
}

\author{
Nataša Kljajić' ${ }^{13}$, Vesna Popovićc ${ }^{14}$, Biljana Grujić $^{15}$
}

\begin{abstract}
Apstrakt
Autori u radu akcenat stavljaju na analizu stanja i ulaganja u sisteme za zaštitu od voda u prethodnom, tranzicionom periodu, posledica poplava iz 2014. godine $i$ finansiranje obnove oštećenih vodnih objekata, kao i na zakonodavni i institucionalni okvir politike zaštite od voda u pretpristupnom periodu.Rezultati analiza ukazuju na nedovoljna ulaganja u uređenje voda $i$ održavanje $i$ dogradnju objekata $i$ sistema za zaštitu od poplava spoljašnjim i unutrašnjim vodama, erozije i bujica u periodu tranzicije. Poslednjih godina, a naročito posle prošlogodišnjih poplava, intenziviraju se aktivnosti na sanaciji, obnovi i izgradnji vodoprivredne infrastrukture za zaštitu od voda. Aktivno se radi $i$ na harmonizaciji zakonodavstva sa odgovarajućim u EU $i$ ispunjavanju obaveza iz potpisanih međunarodnih konvencija u ovoj oblasti.
\end{abstract}

Ključne reči: poplave, vodoprivredna infrastruktura, mere zaštite, upravljanje rizikom.

12 Rad je deo istraživanja na projektu broj 46006: “Održiva poljoprivreda i ruralni razvoj u funkciji ostvarivanja strateških ciljeva Republike Srbije u okviru Dunavskog regiona”, koji finansira Ministartsvo prosvete, nauke i tehnološkog razvoja Republike Srbije.

13 Dr Nataša Kljajić, naučni saradnik, Institut za ekonomiku poljoprivrede Beograd, Volgina ulica br. 15, 11060 Beograd, Srbija, E-mail: natasa k@,iep.bg.ac.rs

14 Dr Vesna Popović, naučni savetnik, Institut za ekonomiku poljoprivrede Beograd, Volgina ulica br. 15, 11060 Beograd, Srbija, E-mail: vesna p@iep.bg.ac.rs

15 Dipl. ing. Biljana Grujić, istraživač saradnik, Institut za ekonomiku poljoprivrede, Beograd, Volgina ulica br. 15, 11060 Beograd, Srbija, E-mail: biljana_g@iep.bg.ac.rs 